mon:a11

INSTITUTE OF DEVELOPMENT STUDIES
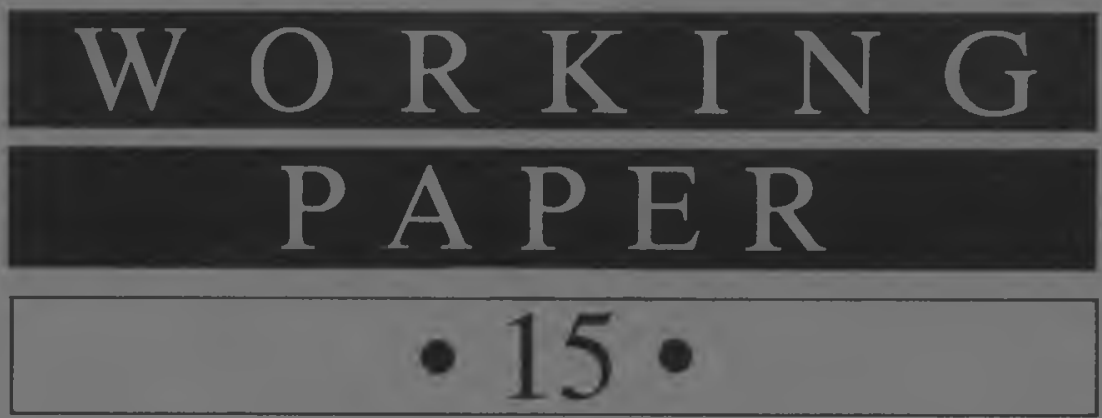

February 1995

Environmental Entitlements:

An Outline Framework for Analysis, and a Mongolian

Case Study

ROBIN MEARNS 


\title{
Environmental entitlements
}

\section{an outline framework for analysis, and a Mongolian case study}

\author{
Robin Mearns
}

\begin{abstract}
The uses and management of renewable natural resources (RNRs), and their consequences for sustainability, are mediated in intended and unintended ways by institutional arrangements. This paper highlights some pitfalls in the existing literature on povertyenvironment linkages in developing countries, and offers an alternative analytical approach based on the notion of 'environmental entitlements'. This more socially articulated approach examines the determinants of effective legitimate command over RNRs, including the rules and institutions that control access, according to the distinctive positions of particular groups of people. The approach is illustrated with reference to the case of pastoral ecosystems under economic transition in Mongolia, and specifically to the community-based management of common grazing land. Three key themes are drawn out, which are of relevance for the management of RNRs in other developing economies undergoing structural reform: (a) the problem of 'institutional scarcity' in the face of new transaction costs; (b) the distinction between the roles of governance and government in RNR management; and (c) the importance of locally evolved, community-based institutions in managing environments at disequilibrium.
\end{abstract}

Key words : - entitlements analysis - institutions - environment and poverty - marginal environments - political ecology - non-equilibrium ecology - governance - transitional economies - collective action -- transaction costs

\section{Introduction}

Sustainable development theory is rather weak on the institutional dimensions of natural resource management. The 'theory' attempts to span a wide ideological and philosophical gulf between preservationist or 'ecocentric' and managerialist or 'technocentric' positions with regard to the relations between society and environment (Pepper 1984; O'Riordan 1988; Redclift and Benton 1994). However, much environment-and-development literature continues to be more or less fixated with population increase and natural-resource degradation and scarcity. Very little of it adequately conveys the extent to which the uses of renewable natural resources (RNRs), and their consequences for sustainability, are mediated in intended and unintended ways by institutional arrangements. This is not to deny that there are serious and growing problems of natural-resource depletion and degradation in many parts of the developing world. But in search of pragmatic solutions to such problems, 
attention should be shifted away from natural resources themselves and towards the humanly devised institutions that - for better or for worse - surround their management.

This argument applies nowhere more powerfully than in the so-called 'resource-poor' or 'marginal' regions, in which many of the world's poorest people live. In such areas it is all too often assumed that the principal problem is low biophysical yields, and that the depletion or degradation of RNRs is an inevitable consequence of their use. In a much more direct way than richer or urban groups, the rural poor derive their livelihoods in large part from legally or socially constituted claims on natural resources, or from the application of their labour in activities that directly or indirectly affect the environment. It is unlikely that there will be a second 'green revolution' appropriate to marginal areas characterised by complexity and diversity of landscapes and livelihoods (Chambers et al. 1989). The 'new' agenda on poverty reduction as espoused by the World Bank and other leading development agencies is remarkably silent on 'resource-poor areas', and speaks primarily of facilitating migration out of such regions (IBRD 1990). But given their continuing importance in the livelihoods of millions of people, resource-poor areas merit much more serious attention from development policy-makers. This demands new approaches to povertyenvironment linkages, both analytically and with respect to policy.

Rather than viewing natural-resource availability and biophysical yields as the limiting factors to rural development in marginal areas, it is often more appropriate, and more positive, to regard 'institutions' as being the true scarce resource (Bromley 1989; McNicoll and Cain 1990; Ostrom 1992; de Janvry et al. 1993; Mearns 1995). Even with an identical mix of available physical factors, a change in the configuration of institutions ${ }^{1}$ can make all the difference in net social product as well as the distribution of benefits among different resource users, including different social groups within the same household or community. Equally, institutional arrangements have an important influence on RNR management and sustainability. Evidence is mounting of the frequently superior capacity of indigenous, community-based institutions to manage complex, resource-poor environments, and gains support from ecological theory. New understanding of ecological dynamics and patchiness in pastoral environments at disequilibrium, for example, shows the importance of local institutional arrangements which have developed around and are well-adapted to dynamic ecology (Behnke et al. 1993; Scoones 1994; Behnke 1994).

\footnotetext{
${ }^{1}$ Institutions are understood here as regularised patterns of behaviour between individuals and groups in society, or "complexes of norms, rules and behaviors that serve a collective purpose" (de Janvry et al. 1993: 566).
} 
This paper draws on new and existing bodies of ecological, social and economic theory that have much to offer in strengthening the analysis of environment-society interactions. Interdisciplinary research in the social sciences (especially anthropology, political science and economics), history and ecology, shows how macro and micro constraints and potentials combine to shape the ways different groups of people gain access to and control over resources, and in doing so manipulate their local environments in ways that may in turn alter those constraints and potentials (Leach and Mearns 1991). This perspective draws on and is influenced by various intellectual traditions, including the 'entitlements' approach of Amartya Sen, extended to encompass the question of effective legitimate command over RNRs; other approaches in the 'new' institutional economics; new thinking on ecology at disequilibrium; and political ecology (Watts 1983; Blaikie and Brookfield 1987; Little and Horowitz 1987; Bryant 1992; Thrupp 1993).

Processes of national-level policy reform directly or indirectly affect local institutional arrangements surrounding the management of RNRs. They therefore have profound social and environmental implications. Foremost among these in the present context are the post-socialist economic and political transitions currently being experienced in developing economies throughout Inner Asia as well as Eastern and Central Europe (Solimano 1993). In an analytical sense, these share much in common with the 'structural adjustment' reform packages implemented in other regions of the world such as Africa, Latin America and South Asia. It is characteristic of all such reform packages that they aim to roll back the frontiers of the State, and variously increase the role of market mechanisms of economic coordination, rather than those attempted through central planning (Kornai 1990). The twin imperatives behind such reforms combined in varying mixes from country to country - are a combination of macroeconomic imperatives, and political demands for greater accountability in decisionmaking.

If the process of economic transition appears to open up a potential window of opportunity at the local level, it also begs important questions about the relationship between government and governance. Taking 'governance' to refer to the exercise of legitimate authority in transacting affairs ${ }^{2}$, a working hypothesis is that good governance in the area of RNR management turns on the relationship between indigenous institutions, social norms, etc., and structures of formal government.

\footnotetext{
2 Author's own definition. For other definitions, none entirely satisfactory for our purposes, see Brautigam (1991).
} 
Government may support good governance in environmental management, or it may undermine it, depending on the precise configuration of formal and informal institutions.

The paper is organised in the following way. First, some pitfalls in the existing literature on poverty-environment linkages are highlighted, and an alternative analytical approach is offered. Drawing on the intellectual traditions outlined above, this alternative approach elaborates the notion of 'environmental entitlements' (Leach and Mearns 1991), and will serve to situate the subsequent case study material in a broader context. Second, reference is made to the case of pastoral ecosystems in postsocialist Mongolia, and specifically to the community-based management of common grazing land in the context of economic policy reforms. Finally, three key themes are drawn out of this experience that seem to be relevant for other developing economies undergoing structural transition: (a) transaction costs and 'institutional scarcity' in the transition process; (b) the distinction between the roles of government and governance in RNR management; and (c) the challenge to orthodox policy approaches that confronts development practitioners operating in environments at disequilibrium.

\section{Poverty-environment linkages ${ }^{3}$}

Some studies of poverty-environment interactions assert that poverty and environmental change are linked directly. Either poverty causes environmental degradation, and /or environmental degradation causes poverty. This implies or assumes that: (a) people's livelihoods are based more or less exclusively on the use and management of environmental resources; (b) poverty and environmental change have a direct causal relationship, and can feed each other in a process of cumulative causation; and (c) poverty is the principal or only cause of environmental change, and environmental change is the principal or only cause of poverty.

This approach commonly assumes poverty to have a negative impact on the environment. That is, poor people are forced to over-exploit natural resources to meet short-term needs regardless of the long-term consequences for their environment, being driven, for example, to overgraze pastures, to cut wood for sale as charcoal, or to cultivate and degrade marginal land. A declining resource base directly contributes to further poverty, and so the process continues in a 'downward spiral' (Durning 1989) or vicious circle. Perhaps the best known among such studies are those drawing empirical evidence from the Himalaya region. Indeed, so numerous are such studies

\footnotetext{
${ }^{3}$ The following three sections draw heavily on Leach and Mearns (1991).
} 
and so apparently coherent the internal logic of the model ${ }^{4}$, that it has acquired the status of a 'theory' in its own right: the Theory of Himalayan Environmental Degradation or THED (Ives and Messerli 1989).

But while some case studies appear to fit this pattern, it is neither self-evident nor well-researched. It is contradicted by studies in which causality appears to run the other way. Careful analysis of some the central assumptions, and examination of the contradictions in the empirical data underlying the THED, have revealed fundamental flaws which, while they do not totally undermine all these causal linkages, certainly call into question the scale on which these processes are presumed to operate, and more importantly point the finger of blame away from the rural peasant (Thompson et al. 1986; Gill 1993).

Other studies also question the assumption that population growth necessarily contributes to environmental degradation. For example, analysis of historical data for Machakos district of Kenya over the last 50 years or so has shown that technical innovation-led agricultural output and environmental quality (measured on a range of indicators) have more than kept pace with rapid population increase (Tiffen et al. 1993). This suggests that under certain circumstances, more people may mean more and better environmental management, bearing out Boserup's theory of population-led agricultural innovation (Boserup 1965). On closer inspection however, such cases rarely point to population alone as the prime causal factor, but rather to various institutional forms that permit creative indigenous management responses in the face of necessity.

Poor people often do manage their environments in sophisticated and sustainable ways, and show themselves able to take the long view, even where conventional economic analysis would suggest that they must be forced to discount the future very heavily. Chambers points to cases in which poor farmers have been observed making sequential physical investments of labour in constructing silt-traps in their fields so as to conserve soil and moisture and progressively build up more productive terraces, an endeavour which yields benefits only in the long run (Chambers 1990). This is analogous to insights from famine theory that suggest that individual rationality is bound up with group survival. Both de Waal for Sudan and Harrell-Bond for Uganda have shown that people under conditions of famine may choose to sacrifice present

\footnotetext{
4 The logic of the THED model can be summarised as follows, where ' $\Rightarrow$ ' implies causality: population explosion $\Rightarrow$ rising demand for fuelwood $\Rightarrow$ deforestation $\Rightarrow$ expansion of cultivated area onto marginal land $\Rightarrow$ increased soil erosion $\Rightarrow$ increase in flooding and siltation in Ganges/Brahmaputra delta.
} 
consumption in order to facilitate investment in and maintenance of social networks likely to he crucial during the post-drought recovery phase (de Waal 1989).

\section{The environmental entitlements approach}

The main difficulty with 'vicious circles' approaches to poverty-environment linkages is that environmental problems are commonly seen only in terms of physical availability or scarcity of environmental resources in relation to the total population 5 . Net deforestation, for example, represents a decline in the availability of forest resources for all groups of people, while its consequences may be especially serious for those poorer people who depend disproportionately on forest resources for their livelihoods.

But it is entirely possible for there to be 'environmental problems' for particular groups of people even in the face of relative abundance of natural resources. The central issue then is one of secure access to and control over those natural resources that are available. Here the concept of entitlements is useful (Sen 1981), developed from a particular view of political morality attributable to Rawls (1972) and in opposition to that of Nozick (1974). The entitlements approach entails "analysis of effective legitimate command [over food, RNRs], and its various channels and determinants, including attention to the rules and institutions that control access, and to the distinctive positions and vulnerabilities of different groups" (Gasper 1993: 690).

In explaining hunger and famines, Sen focuses especially on (the failure of) entitlements to food acquired by production and trade activities, usually through the market mechanism (Sen 1981; Drèze and Sen 1989). The argument rests heavily on notions of individual private property, backed up by statutory law, and is primarily concerned with entitlements to material goods (principally food). Others have regarded this as too restrictive a focus, on the grounds that entitlements to food can also be secured through claims on and investment in a wide range of social institutions and networks within the 'moral economy' and backed up by systems of customary law (Scott 1976; Swift 1989). While they are important in the analysis of food security, the role of such collective or socially-grounded claims is even more significant in understanding the environmental entitlements of poor people, for example in relation to common property resources.

\footnotetext{
${ }^{5}$ In the context of environmental resources, 'availability' refers to both quantity and quality of resources.
} 
Care needs to be taken with the application of an entitlements approach in understanding effective legitimate command over RNRs. Although in his analysis of food entitlements, Sen claims he does not use the concept of 'entitlement' normatively, he has come in for criticism on these grounds. The very word in the English language conveys the meaning of a morally sanctioned 'right'. When referring to command over environmental resources, one needs to be perhaps even more precise in the use of the term. One of the most helpful statements of Sen's position is when he introduces the notion of 'capabilities' (Sen 1984, chapter 13). Sen regards the process of development as the expansion of people's entitlements and their capabilities enjoyed by the use of these entitlements. Whereas for Sen, a person's entitlement focuses attention on the (material) good in question, introducing the notion of capability focuses attention on features of people or groups in relation to goods. What is important is not valuing the environment per se (addressing the characteristics of environmental goods), but of valuing particular institutional arrangements or rules sets that enable the person or group of people in question to avail themselves of the desired characteristics of that good.

What is permissible is to view the right to a livelihood - the basic human right - in normative terms. It is then a secondary question how that livelihood is secured. A basic premise of much of the literature on poverty-environment linkages is that the rural poor in developing countries happen to derive a disproportionate share of their livelihood from their environments. In a similar vein, the urban poor happen to be more frequently prevented from earning a livelihood as a result of their unhealthy environments than the urban rich. Insofar as alternative livelihood sources are lacking, entitlements to use environmental resources (material and energy inputs, clean water etc) will remain more important to poorer than to richer people. The relative importance of such environmentally derived entitlements in meeting livelihood needs for particular groups can, in principle, be mapped out empirically. This is not to imply in some normative sense that they should derive a livelihood directly from the environment. Indeed, very often the most appropriate forms of policy intervention are those which widen the range of options open to poorer people so as to reduce their net dependence on the environment (Lipton 1991).

Unlike food entitlements, the concept of environmental entitlements encompasses 'ability to make effective use of' as well as simply 'access to' (environmental) resources. This difference is important since it emphasises the management of environmental resources in securing a livelihood. The focus on management, in turn, shifts attention towards the conditions that both enable and constrain the ways people 
manage and use their local environment. Again, these conditions refer to prevailing rules sets or configurations of institutions.

'Environmental entitlements', then, can be defined as "the combined outcome of both (a) the environmental resource bundles that people have command over as a result of their ownership, their own production, or their membership of a particular social or economic group; and (b) their ability to make effective use of those resource bundles" (Leach and Mearns 1991: 10). They therefore mediate the effects of 'poverty' on the use and management of environmental resources, and in turn mediate the ways environmental degradation contributes to processes of impoverishment.

To take a simple example, consider herding contracts. These are an institutional arrangement that affects the nature of animal management (Toulmin 1992). The only source of income for a herder who does not own the animals in her care may be milk, so that she will tend to milk them harder than would owner-herders. Animal owners desire control over their animals, and may therefore restrict opportunities for non owner-herders to practice long-distance transhumance. In both instances, herding practices may be expected to be relatively less environmentally benign than in cases where owners herd their own animals.

Similarly, the reasons why farmers may move into herding and herders into farming frequently vary by wealth category. Richer farmers tend to move into livestock ownership, and richer herders into cropping, as a form of investment, while poorer farmers and herders tend to switch or diversify livelihood source out of necessity or risk aversion. In either case, these underlying reasons also affect management practices. The rich are more likely to hire additional labour so as to minimise competition for labour between cropping and herding, whereas the labour-constrained poor are likely to face trade-offs between their agricultural and their livestock activities.

A wide range of factors, then, may influence the environmental entitlements of particular groups of people, whether by affecting access to environmental resources, or by affecting people's ability to make effective use of them. Some of the most important factors include natural-resource tenure arrangements, labour access and arrangements, claims on and investments in social institutions and networks, capital endowments, and technology, skills and knowledge. The role of economic incentives, transmitted through the price mechanism to influence the decisions individuals and enterprises make about natural resource management, is too often emphasized in the 
literature to the exclusion of other factors structuring environmental entitlements, but is nonetheless of major importance and bridges the gap between the macro and the micro levels. These sets of factors are dynamically interrelated; processes of environmental change and of impoverishment can lead to changes both within each set and in the ways they interact.

A further consideration is the question of changes in environmental entitlements over time. Although they are outcomes of various structuring processes, environmental entitlements themselves are dynamic, and may improve or decline ('fail'). Entitlement failure either worsens poverty, or contributes to environmental degradation because people are no longer able to manage environmental resources effectively. However, it is possible that poor people could lose as a result of availability decline with no change, or even alongside an improvement, in the distribution of environmental entitlements. The central issue here is one of sustainability, or ensuring both environmental availability and environmental entitlements for present and future generations. Poor people's environmental entitlements, or the availability of environmental 'quality' for them, could improve in the short run at the expense of the long run, not least in the context of population growth.

Poor people usually earn a livelihood by means of a diverse range of activities. Environmental entitlements are just one among several sources of livelihood for poor people. Normally the most important among others is the sale of labour. Nevertheless it is commonly observed that environmental entitlements are especially important in the livelihoods of the poor, largely because of a lack of alternative choices. The income/ livelihood sources of poor people also tend to be variable as well as diverse. Vulnerability is a measure of this variability in the face of more or less continuous stresses, or contingencies and other sudden shocks (eg. drought, price shocks, disease) and people's capacity to cope with and respond to them (Chambers et al. 1989). It is the most critical dimension of poverty in relation to environmental entitlement or availability decline, because it emphasises the importance of net asset position in guarding against the 'ratchet' effect by which people may be driven to deplete or degrade environmental resources. Environmental entitlements can be thought of as one among several kinds of asset which can be drawn down or built up in strategies for dealing with shocks and stresses of various kinds.

Just as the stresses and shocks that people face in making a livelihood may or may not be environmental in origin, so in turn the policy responses for ensuring sustainable environmental management may themselves address areas apparently unrelated to 
environmental concerns. Some of the most important of these relate to contemporary policy approaches to poverty reduction, including employment creation and safety nets, including investment in human resource development such as health and education (IBRD 1990; Lipton et al. 1992). While aimed at poverty reduction rather than environmental management, these policies may have the side-effect of reducing the overall dependence of the poor on environmental entitlements, or reducing their vulnerability to environmental entitlement failure.

\section{A simple analytical framework}

The concept of 'environmental entitlements' is intended to draw attention to the usually indirect nature of the linkages between poverty - or wealth - and environmental change. It aims to supplement an assessment of relative naturalresource scarcity with a more socially articulated appreciation of the institutional issue of access to and control over resources for particular groups of people, and how these change over time. The overall framework is shown in diagrammatic form in figure 1.

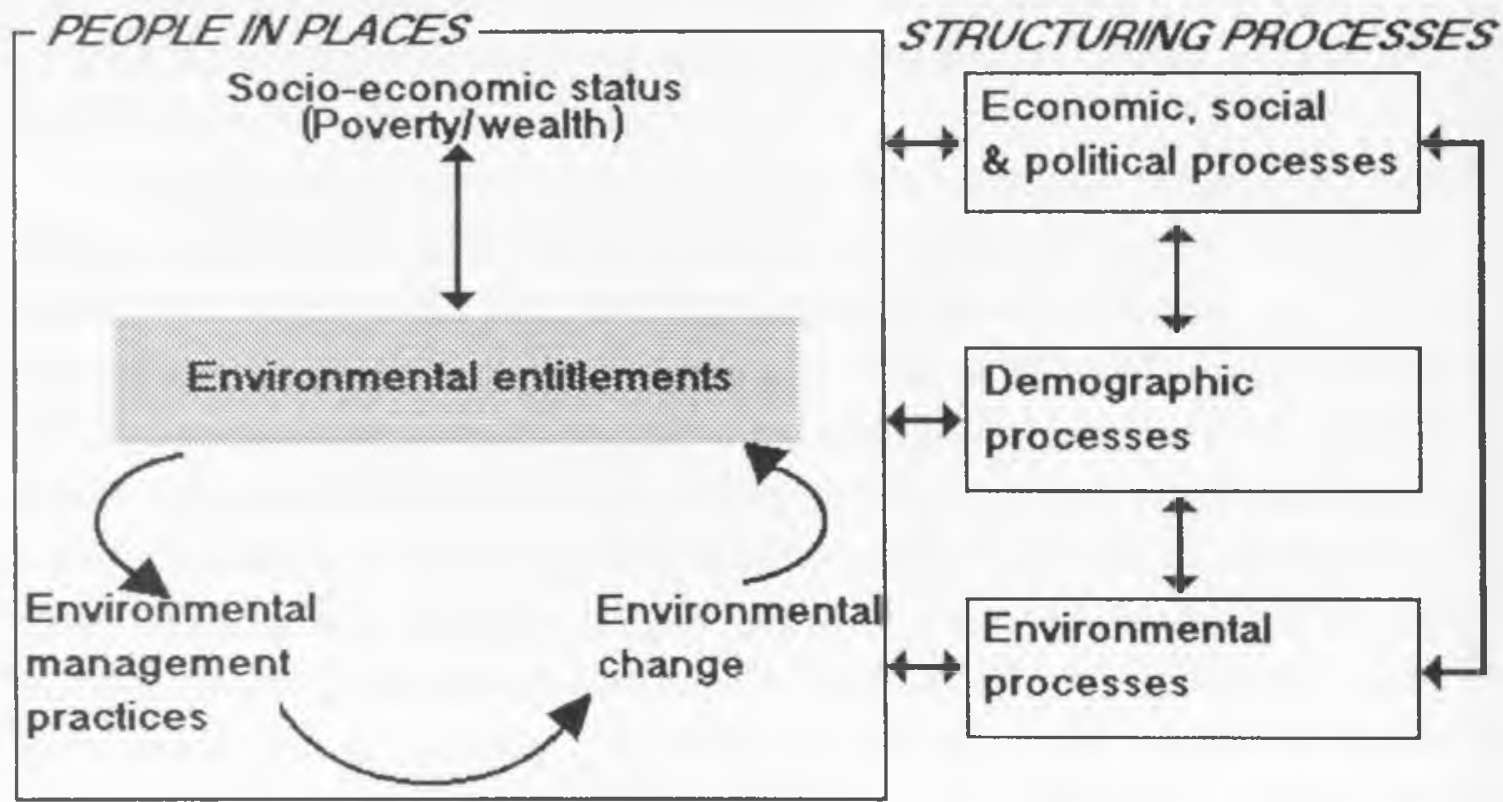

Figure 1 The environmental entitlements framework 
There are two main levels of analysis in this simple framework. The first, on the left of the diagram, applies to particular individuals or groups of people (and their socioeconomic status) in particular environments (and their status over time). This scale level is usually that of the locality, eg. household, village or neighbourhood; or a watershed or grazing unit. It is at this level that environmental entitlements influence the resource-management decisions that people make, with intended or unintended consequences for the natural-resource base that may in turn alter people's environmental entitlements.

The second level is that of 'structuring processes'. These lie to the right of figure 1. From this viewpoint many of the phenomena and interactions discussed so far prove to be manifestations of underlying causes operating elsewhere, at scales from the local up to the international or global. Many of these processes are exogenous to 'people in places' in the sense that people in those localities have no direct influence over them. They include political, social and economic factors, encompassing policies, processes, and the context within which they operate; environmental change, encompassing both natural and human-induced changes; and demographic processes, which encompass both 'in situ' population change and migration. These structuring processes are themselves interrelated in diverse and complex ways. As the two-way arrows show in figure 1, they interact with the dynamics of processes at the level of 'people in places' so that, in effect, the 'system' never settles.

Contemporary post-socialist transitions are an example of the kind of macro-level shock wrought by far-reaching changes in economic and political institutions. This may translate into a substantial change in the rules of the game for local resource managers, by altering their environmental entitlements, and in turn possibly altering the manner in which they manage natural resources. At the same time, the cumulative effect of local responses may reflexively alter the course of the macro reform process.

\section{The case of Mongolia}

The process of Mongolia's post-socialist transition proper began in early 1990 . Although economic reforms inspired by Soviet perestroika had been under way since 1986 (Milne et al. 1991; Collins and Nixson 1993), it was not until the prodemocracy movement of early 1990 that the building of a market economy began in earnest. Mongolia is a land-locked country with a population of a little over two million people, half of whom live in rural areas and depend to a large extent on livestock for their livelihoods. Among transitional economies of Inner Asia, Mongolia is unique in that it was formally independent of the USSR during its 70 years of 
socialism and has therefore been able to liberalise more rapidly than its neighbours in former Soviet Central Asia. It is also distinguished from the autonomous regions of Inner Asia under Chinese control in that political reform has also accompanied economic reforms in Mongolia.

Mongolia has privatised very quickly indeed by the standards of other transitional economies in Eastern Europe: "by the end of 1992, more than $80 \%$ of the industrial, service, trade and agricultural sectors had been privatised, judged by both the number of enterprises and the amount of capital stock" (Korsun and Murrell 1994, p2). The phrase economic 'transition' implies a greater degree of continuity in formal economic institutions than is in fact the case. During the early years of reform Mongolia experienced a shock so severe that it threatened economic collapse, and the process remains far from smooth (Murrell et al. 1992). A conservative estimate of the overall impact of this shock put the expected decline in real national income between 1990 and 1992 in the order of 30-35 per cent (MPR 1991a; Lee 1993).

Agriculture remains the most important sector of the economy, accounting directly for some $20 \%$ of national income and $30 \%$ of national employment, and indirectly for a further significant share of national income and employment in agricultural product processing and marketing. Agricultural products also make up around a quarter of all exports and foreign exchange earnings. Perhaps even more important in the straitened circumstances following the cessation of CMEA credits and imports of cheap food, fuel and spare parts from the former USSR, is the contribution of domestic agriculture to food supply. By far the most important sub-sector within agriculture is pastoral livestock husbandry, which accounts for around $75 \%$ of gross output in agriculture. This figure is likely to be increasing given the difficulties faced by the former state farms, designed to produce wheat and liquid milk for urban consumers during the winter using petroleum-intensive technology which has become virtually moribund. Owing to low producer prices, rapid inflation, and severe transport constraints, much of the output of livestock and livestock products is untraded (Edström 1993). The pastoral collectives, having existed since the 1950s, have virtually all been transformed into limited and joint-stock companies and cooperatives.

Figure 2 attempts to flesh out the bare bones of the environmental entitlements framework elaborated earlier. Several examples are offered to show how the process of economic transition in Mongolia translates into changes in the environmental entitlements of particular herding households and their individual members. Only a few of the factors that influence these entitlements are considered here, namely: 
natural-resource tenure arrangements that affect access to grazing and water; access to labour for herd management; and the related issues of kinship networks and the reemergence of the customary khot ail, or camp of several cooperating herding households. Each of these has implications for the ways in which animals and natural resources - especially pasture - are managed, which in turn affects local processes of environmental change.

The most important aspect of environmental change that is 'exogenous' to herding households in particular places for present purposes is the question whether or not in Mongolia there is a downward trend in the availability and/or quality of forage from natural pastures. Many Mongolian as well as outside observers perceive that there is such a trend, and that it is directly related to the number or density of grazing animals, or overgrazing. For example, the Asian Development Bank is planning a livestock feed resources management project which has as a primary justification the belief, based partly on data gathered by the Mongolian Institute of Botany, that a very high proportion of pasture land is already degraded or at serious risk of degradation from overstocking.

Mongolian herders themselves see things differently. They distinguish between pasture that is 'eaten' and pasture that is degraded (Fernandez-Gimenez 1993). 'Eaten' areas are caused by a temporary concentration of people and animals in one place, but usually regrow during the subsequent growing season without permanent change in species composition or productivity. Where seasonal pasture deferral is practised, as is common in many parts of the country (Bazargür et al. 1992; Mearns 1993a, 1993c), many pastures are likely to be grazed out in this way at the end of a season. Degraded areas, on the other hand, are permanently altered in species composition and productivity and are characterised by soil loss and sandiness; herders more usually attribute such degradation to overland vehicular traffic and compaction by agricultural machinery since, they argue, animals do not damage plant root systems by grazing. The Mongolian Government's National Report prepared for UNCED shares this assessment (MPR 1991b). 
PEOPLE IN PLACES

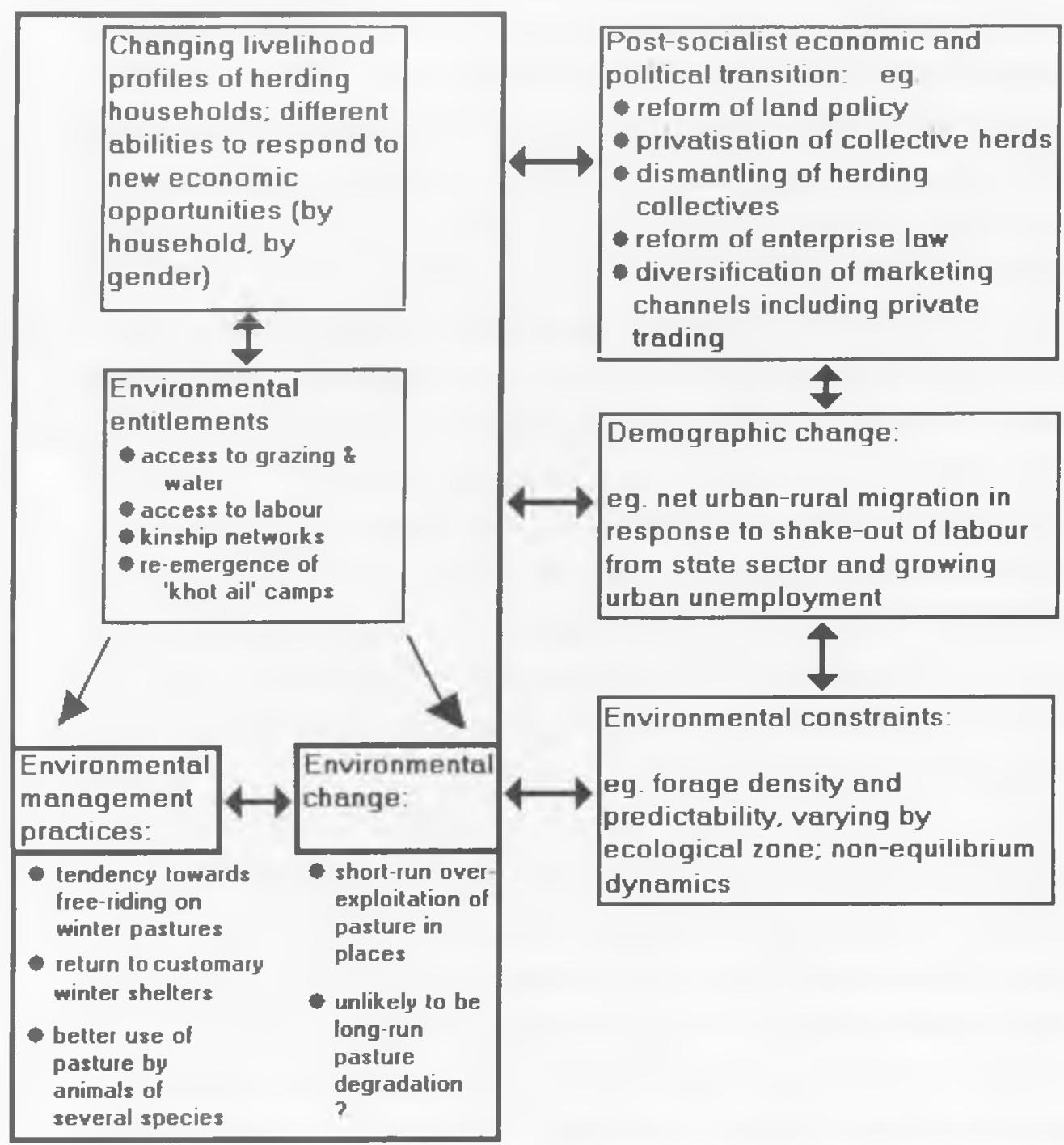

\section{STRUCTURING PROCESSES}

privatisation of collective herds

diversification of marketing channels including private

ccess to grazing ?

abilities to respond to

opportunities (by

gender) trading

Demographic change:

g. net urban-rurel migration in state sector and growing uban unemployment

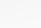

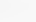


The availability of forage resources is certainly an important limiting factor in livestock production in pastoral environments as dry as those in Mongolia and other parts of Inner Asia, and in which by far the greater part of animal nutrition requirements is met from natural pasture. In fact, variation in forage resource availability and predictability from one ecological zone to another can be shown to explain a good deal of the regional variation in patterns of territoriality among Mongolian pastoralists and the informal arrangements that they have evolved to coordinate access to common grazing land and key point resources (eg. wells) (Mearns 1993c). In areas of relatively low forage density and predictability - such as the desert steppes in southeastern Mongolia with annual precipitation totals of around $125 \mathrm{~mm}$ and a coefficient of variation (CV) in precipitation of $52 \%$ - pastoral land tenure is characterised by an opportunistic grazing strategy. A high degree of mobility and flexibility of movement permits access to localised patches of forage that vary in quantity and quality from place to place and from time to time. By contrast, in areas of relatively higher forage density and predictability - the 'typical' steppe zone towards the North, for example, with an annual precipitation of around $300 \mathrm{~mm}$ and a $\mathrm{CV}$ of $30 \%$ - a much more geographically stable territorial system operates.

Although relative natural-resource availability and variability explain a good deal of the variation in territorial behaviour among pastoralists in different ecological zones, a full understanding of pastoral land tenure arrangements and their change or continuity over time also requires that the influence of changing political and economic conditions and public policies be taken into account (Mearns 1993c). The period of collectivised production in Mongolia saw a surprising degree of continuity in land tenure arrangements in particular localities. Public policies during the period often tacitly underwrote customary practice, such as the norms and customs that surrounded the allocation of particular winter shelters. There were also significant changes however. A range of public policy-related factors, while they led to a general rise in the living standards of herders, had the effect of reducing herder mobility. Territorial behaviour became to some extent delinked from ecological factors, as a result of public action to minimise the impact of environmental stress on individual herders. This included investment in winter shelter construction, water supply, and the subsidised provision of animal feed supplements and transport.

The period of decollectivisation has seen a partial return to patterns of territorial behaviour more directly influenced by ecological factors and less by public policy. Most obvious have been the responses of individual herders to the dramatic decline in collective provision of transport and animal fodder, including a return to cooperative 
hay-making within neighbourhood groups, and mutual assistance with base camp moves using draught animals. Many of these re-emergent forms of cooperation are based in local kinship-based networks. This transition process has been far from smooth however, and is also far from complete. In the short term at least, there has been an increase in the incidence of abuses of local norms of coordination over pasture use. Some of the reasons for this appear to include the large numbers of newcomers to herding, and the lower opportunity costs of free-riding behaviour by them.

Evolved coordination norms over pasture use include seasonal pasture deferral in the more productive regions; and priority to customary owners of winter and spring shelter sites, to previous users of a pasture site where some mark or a dung pile has been left, or to first-comers. As with many social norms, these informal rules have become largely internalised in herders' everyday patterns of behaviour, so that they are rarely acknowledged explicitly. It is usually only when conflicts arise, requiring conscious arbitration, that they are shown to be in evidence. One's reputation among neighbouring herders (many of whom are relatives), and the need to cooperate with them in other activities such as herding, hay-making and the like, are sufficiently strong most of the time that herders tend to abide by local norms of pasture use (Mearns 1993b).

In the period of economic and political transition following decollectivisation however, two contradictory trends can be identified: one which threatens to undermine coordination norms around local pasture use, and one which could potentially strengthen them. The first of these trends is the atmosphere of uncertainty that characterises the reform process. This contrasts markedly with the rigidities and limited individual freedoms of centuries of hierarchical, feudal organisation, followed by 70 years of central planning. The feudal state prior to collectivisation interfered relatively little with the day-to-day business of herd management, but provided a stable, ordered social formation within which it could go on. Similarly, under collectivisation, the bounds within which herders operated were clear, known and predictable.

Under the present conditions of structural chaos however, the necessary degree of institutional stability required for the upholding of group norms regarding land tenure, and for the potential exercise of sanctions within local groups, is absent. This uncertainty makes it difficult for herders to form mutual expectations of each others' actions. It tends to heighten the assurance problem of not knowing to what extent 
other herders are likely to stint, or voluntarily exercise restraint, in their use of pasture. Other things being equal, individual herders are likely to perceive a lower threat of sanctions against free-riding behaviour. That is, the opportunity cost of attempting to maximise individual gain from the available pasture is perceived to be lower. While economic and political conditions are changing rapidly, it is difficult to learn from past experience in order to anticipate the behaviour of others, since a particular conjuncture of circumstances influencing one's own and others' decisions may never be repeated.

In one forest/mountain steppe area of Arkhangai province, for example, an orderly system of seasonal pasture deferral was beginning to come under threat during 1992 , following the dissolution of the collective and the privatisation of its herds. A large group of more than twenty herding households moved to their autumn camps much earlier than usual. Those who moved first claimed at the time that they had moved only to build new shelters and stockyards following privatisation, but remained for several months, during which time they were joined by others. The group included both experienced herders and newcomers who had only recently acquired animals in the privatisation of the local collective's herds. They had moved against the advice of the bag (sub-district) leader, who was told that if he wanted them to return he would have to provide transport; they knew he would be unable to do so, given shortages of fuel and vehicle spare parts. Other local herders, normally members of the same community group, regretted not having moved with the renegade group, since they had missed out on the best grazing that year from their autumn pastures. However, the renegade group did not expect to take such action the following year, since they felt they had learned from their mistake during 1992, when the autumn pastures became heavily congested and grazed out before the end of the season (Mearns 1993a, 1993b).

Recent changes in the structure of the rural economy have contributed to this trend favouring individual free-riding behaviour. Most important among these is the surprising demographic factor of net urban-to-rural migration. On average, the total number of herding (rural) households across Mongolia increased by 25 percent during 1992. The individual figures for areas close to the capital city, Ulaanbaatar, were considerably higher (PALD 1993). This includes several different types of household, but numerically the most important are families leaving the city for the countryside in response to rising urban unemployment and economic uncertainty, who acquired animals through the privatisation of state and collective herds. These are 'newcomers' to herding, or urban-to-rural migrants. Field data from the relatively remote provinces 
of Arkhangai and Dornogobi suggest that they made up about $20 \%$ of total households in the communities surveyed.

This counter-intuitive, and probably temporary, increase in the number of herding households reflects a lack of alternative sources of livelihood. Livestock herding is perceived not so much as a secure and productive economic opportunity in itself, especially given low prices and formidable marketing constraints, but it does at least provide some measure of household food security. Even if producer prices were to rise substantially, the extra incentive to livestock production would be unlikely to lead to a commensurate rise in the total number of animals. A severe winter-spring feed constraint appears to have operated to keep the national herd below a ceiling of around 25 million head for several decades, in spite of efforts to increase its size by means of heavily subsidised fodder production and distribution under collectivisation (Swift 1995).

Even without an increase in total animal numbers, the increase in the number of herding households poses potential problems for sustainable land management within existing herding communities. The newcomers are usually less experienced herders, and less aware of the importance of local customs to coordinate use of grazing land. For example, they are more likely to stay at their winter pasture sites than to move to new pastures during the spring, autumn and summer. Newcomers also tend to move irregularly because they do not yet have winter shelters and established herding relationships within groups. They are often less integrated into rural communities, and are therefore less likely to take into account the benefits of cooperation with other herders in other ways, such as shared herding, helping to move camp, looking for lost animals, or making hay. Experienced herders of long standing in the community are more likely to cooperate with their neighbours over the use of grazing land, because they know that there are additional benefits to cooperation. The new herding households' primary loyalties are likely to remain towards the towns, rather than to the rural community.

In opposition to this trend favouring individual free-riding behaviour is the reemergence of local customary institutions, notably the khot ail, within which herders engage in various forms of mutual assistance. Under collectivisation, the decline of such labour-pooling arrangements was a contributory factor in the decline of customary mechanisms for coordinating and regulating pasture use and the arbitration of land disputes. Conversely, their strong re-emergence in contemporary Mongolia can be expected to increase the incentives for collective action in the management of 
common pastures. As argued elsewhere, this second, positive trend provides a key opportunity to strengthen pasture land management by building on and strengthening local community institutions as an integral component of land policy reform (Mearns 1993a; PALD 1993).

Lastly we should consider explicitly how the environmental entitlements of particular herding households and their individual members vary, even when faced with similar changes in macro-level 'structuring processes'. Once again, the link to environmental management practices and potential environmental change in these cases operates via the intermediate set of decisions around herd management, since livestock products are the principal livelihood source. Differentiation among herding households and their individual members takes several forms 6 . Different levels of skill and experience in herding have already been discussed in relation to newcomers to herding.

Differentiation between household members should not be underestimated, especially in the case of gender, which may critically affect the capacity of different individuals to respond to new economic opportunities that may arise with economic reforms. Women shoulder the greater part of household reproduction tasks (childcare, cooking, cleaning, etc) as well as a major share in production (eg. milking and dairy product processing). Owing to this double-bind on their time, women are usually much less mobile than are men, and less likely to be in a position to take advantage of new opportunities offered by trading and the marketing of livestock products.

Wealth differences are significant and growing (Cooper 1993). The size of the household herd is invariably the most important among the criteria identified in participatory wealth ranking exercises ${ }^{7}$, but other criteria consistently mentioned by herders are holdings of other assets (eg. gold and silver valuables and saddlery) and connections with influential people in the administration or 'friends in high places' (Mearns et al. 1992). Information on household demographic structure is implicit in the individual scores of households in such ranking exercises: households with a young age structure and high dependency ratio tend to be perceived as less well-off than those with more adult members. This reflects the lifecycle of a herding

\footnotetext{
${ }^{6}$ Unlike in other parts of Inner Asia, ethnic divisions are not very significant in Mongolia. Over 90\% of the population are Khalkh Mongols, although significant pockets of other ethnic groups (eg. Kazakhs) are found in the Western provinces of Khovd and Bayanölgii.

${ }^{7}$ Wealth ranking (Grandin 1988) is one of a very large range of participatory research methods now in use for eliciting self-assessments of well-being and other forms of situational analysis on the part of local communities. For the most up-to-date survey of the state-of-the-art of 'participatory rural appraisal' (PRA), see Chambers (1994a, 1994b, 1994c).
} 
household: it takes some years to build up a large herd and to become proficient in herding and animal management skills.

A 'stepped' relationship tends to operate between the household size and herd size: the number of animals may increase only up to a certain point before additional household members are required to care for them. If animals of several species are considered, this relationship become more complex. There are significant economies of scale to be gained in cooperating with other households so as to pool the herds of large (cattle/yak and/or horses) and small stock (sheep and goats), and to take turns in taking them to pasture each day.

During the period of collectivised production (1940s-80s), collective members were allocated a certain number of animals of a single species by their collective, and were paid a salary for fulfilling their production quotas. After animals began to be privatised and restrictions on private herd sizes were lifted around 1991, most herding households returned to the customary practice of maintaining a household herd with animals of several different species (Mearns 1992). Two important reasons for this seem to have been to increase the range of livestock products that could be produced within the household, given the difficulties and high costs incurred in obtaining essential items of food and clothing from the poorly functioning state sector or the still fledgling system of private traders; and to spread risk. Under collectivised production the pastoral collectives - effectively the state - bore the brunt of risk in livestock production by supplying subsidised inputs in the form of supplementary livestock feed during harsh winter periods, water, transport for moving camp, etc., and by making direct social welfare transfer payments. The transition to a market economy has meant that much of this risk is now being shouldered directly by individual herding households (Mearns 1993a; Templer et al. 1993).

In response to this increased risk burden, herding households have reponded in several ways, depending on their existing endowments of labour. One already alluded to is to increase various forms of mutual assistance with other households, notably through the kinship and other ties that bond the khot ail together. A second is the withdrawal of children (usually boys) from school owing to the increased demand for family labour following the start of privatisation of the collectivised herds. As table 1 illustrates, drawing on data for a single former brigade of a collective in a desertsteppe area of Dornogobi province, this practice is related both to the size of household herds (using wealth rank as a proxy) and to household size and age structure (Mearns et al. 1992). Although the sample size here is small $(n=75)$, the 
data show a bimodal distribution. Households with absentee school children fall either in the 'poorer, large' quadrant (lower left), or in the 'richer, small' quadrant (upper right) of the matrix. The former need additional labour because they have few workers relative to dependents. The latter need additional labour because they have larger herds overall, while adult children may be attracted away from herding by alternative economic opportunities such as private trading. The labour constraint in herding has become more severe as households diversify their herds, but it takes different forms according to the wealth status, size and life-cycle stage of the household

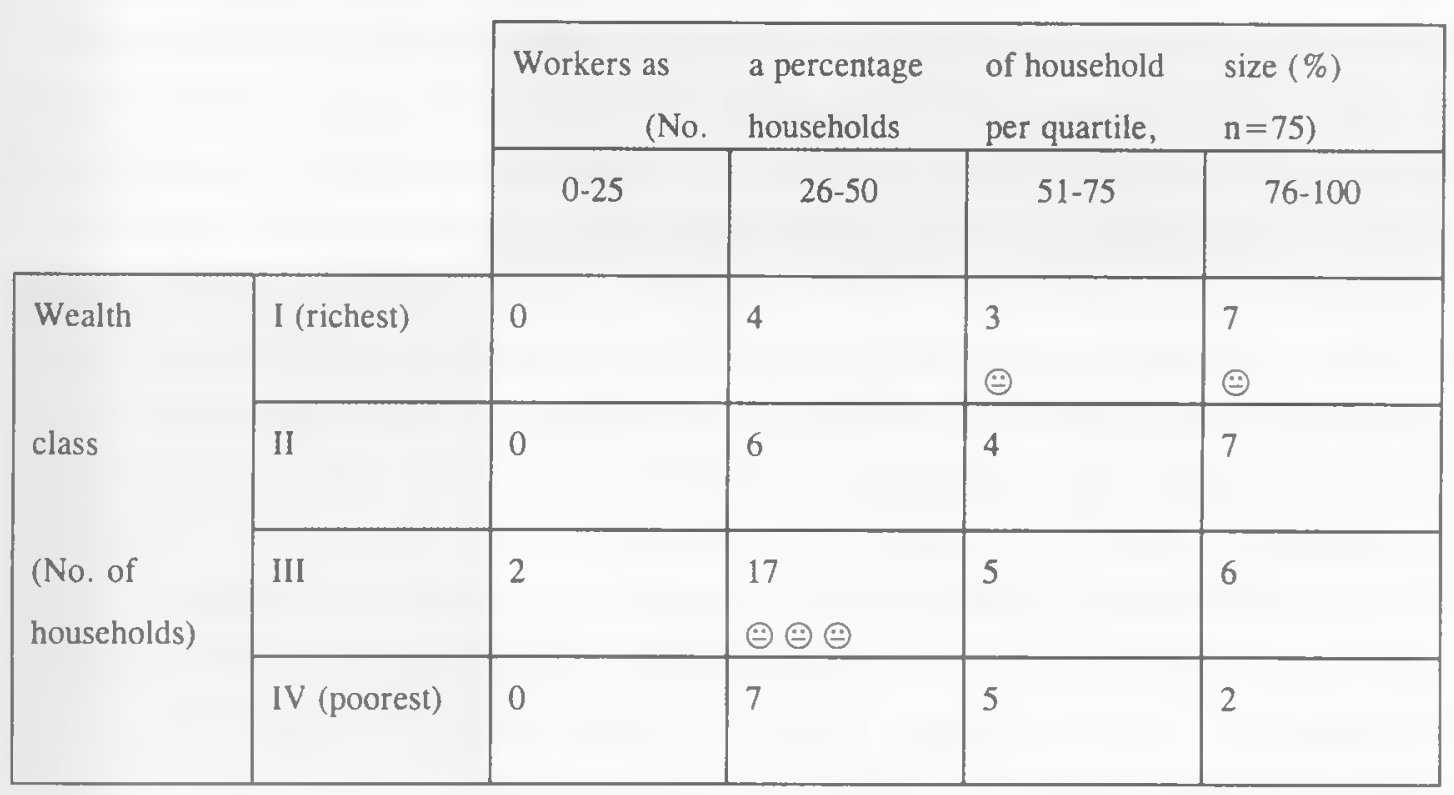

Note: $:$ indicates households with a child known to be permanently absent from school Source: Mearns et al. (1991)

Table 1 Wealth, labour availability and school absenteeism

Analysis of annual household incomes in six sample districts in 1993 found that the average per capita incomes (net of own consumption) of the poorest households were around a third less than those of middle income and nearly half of those of richer households (Cooper 1993). This resulted in clear differences in income and expenditure patterns between richer and poorer households. The proportion of sales of livestock and livestock products was highest for the poorest households, owing to their need to sell products in order to purchase basic goods (eg. flour) in spite of the unfavourable terms of trade that confront rural producers. Wealthier households have the option of withdrawing from the market until conditions are more favourable. 
Indeed, the poorest households in the sample spent the highest proportion of their income on purchased foodstuffs (especially flour) and least on clothing and essential inputs such as prepared animal fodder and hay. Instead of the latter they relied on home-produced feed supplements, at some potential cost in terms of animal productivity.

\section{Conclusion: three themes}

This paper has argued that the uses of RNRs, and their consequences for sustainability, are mediated in intended and unintended ways by various forms of institutional arrangement. In the case of Mongolia, sustainable RNR use and management is seen to depend on the continuing viability of pastoral management systems well adapted to a harsh and variable environment, as has been documented throughout this century by early Soviet geographers and others (Aubin 1993). There are new constraints, however, such as localised population pressure, and new forms of market penetration, to which there need to be appropriate institutional responses. Existing theory around the notion of sustainable development remains inadequate in relation to these institutional dimensions of RNR exploitation and preservation, although significant progress is being made in this regard. The environmental entitlements framework presented here is intended as a further step in this direction.

From the Mongolia case study set out in this paper using the environmental entitlements framework, three salient themes emerge. These are relevant to a consideration of the links between environment and development in all of the postsocialist transitional economies of Asia, as well as in considering the institutional dimensions of RNR use and their role in ecosystem preservation more generally.

The first theme is institutional scarcity. One of the most powerful insights from recent social science theory that has yet to be placed squarely on the environment and development agenda is from the new institutional economics: "when it is costly to transact, institutions matter" (North 1990, p12). Transaction costs include search costs (identifying opportunities), bargaining costs (agreeing among the relevant parties to a certain course of action), and monitoring and enforcement costs. Institutions operate to reduce or offset transaction costs by regularising and making predictable transactions between individuals. All forms of property - private, common, or state involve transaction costs. Clearly defined property rights, whether formal or customary, represent an institutional arrangement that reduces uncertainty in exchanging and enforcing rights to gain access to and control particular resources (Eggertsson 1990). Coordination norms around pasture use in Mongolia, for example, 
are such ingrained social norms for most experienced herders that the transaction costs incurred in deciding who gets to graze where and when are reduced to a minimum: the institutional arrangements operate at the level of the sub-conscious.

Owing to the extremely high transaction costs entailed in making a major economic and political transition at the level of an entire economy, the value of pre-existing institutional arrangements for ensuring that economic affairs may continue should not be underestimated. In Mongolia's earlier macroeconomic transition - from feudalism to socialism - with the advent of central planning and collectivisation, the continuity of certain institutional arrangements may have saved the day. For example, had the reform of administrative boundaries been fully complete in the 1930s, so that herders would have been prevented from moving across administrative boundaries even when these dissected their customary routes of transhumance, the consequences for livestock production could have been disastrous. As it was, herders continued to move illegally across the new district boundaries when necessary, thereby safeguarding production on behalf of the collectives; the state was, fortunately, unable adequately to police such transgressions. In a similar vein, recent research in Mongolia has shown that Mongolian citizens used their privatisation vouchers to invest in the enterprises that employ them, even when this is not in their direct economic interest. This includes the new rural enterprises that have replaced the herding collectives. These investors apparently seek to retain an environment that is 'known and comfortable' and that minimises disruption (Korsun and Murrell 1994).

The second, related theme is the distinction between government and governance. These are not at all the same thing. Governance is broadly understood to refer to the exercise of legitimate authority in transacting affairs. It involves the maintenance of social order through endogenously evolved sets of rules, or some combination of locally evolved and externally imposed rules sets. Government, by contrast, is one aspect of governance, referring specifically to the role of external authorities in maintaining social order. In the absence of government, either because external sets of rules have not so far been devised in specific contexts (such as legislation designed to protect the environment), or because weak administrative capacity hinders the enforcement of law and policy, governance - or the lack of it - becomes entirely a question of endogenously evolved sets of rules.

With respect to natural resources, government refers to the de jure set of rules as set out in statutory law and state policy relating to natural resource ownership, tenure and use; and the administrative framework through which it is implemented. The broader 
concept of governance refers to the sum of rules sets that apply de facto. It thus includes the customary rules that also influence who has access to and control over natural resources, how, and at what times; the extent and manner in which those rules are monitored and enforced; and the traditional or other systems of authority through which they may be legitimated. In some cases, the operation and manner of enforcement of statutory law may be in harmony with customary practices, in which case government supports governance. Perhaps more commonly, in cases such as the introduction of smaller administrative units in Mongolia during the 1930s, the de jure and de facto sets of rules come into conflict. Government may undermine customary structures of authority that contribute to the successful regulation of natural resource use, and in so doing hinder effective governance. It is emphasised that neither governance nor government, or the specific rules sets that make them up, entirely determine actual natural resource management practices; however, they are one of the most important influences over patterns of interaction between resource users.

The final theme is the question of ecologies at disequilibrium, and brings us full circle to the issue of natural-resource scarcity. Earlier in this paper the question of forage density and predictability was raised. In practice, there is a high degree of observed covariance between low resource density and low resource predictability. In arid environments precipitation is the major limiting factor on plant growth, and is generally characterised by a high interannual coefficient of variation (CV). This is one of the cornerstones of the recent literature on 'new' ecological thinking as applied in the context of range ecology and management in dryland Africa (Westoby et al. 1989; Behnke et al. 1993; Walker 1993; Scoones 1994). In this literature attention is drawn to a continuum between equilibrial and non-equilibrial systems, according to the degree to which the biotic components of the grazing ecosystem (net primary productivity of forage, wild and domestic herbivore populations) achieve stability such that their dynamics have a significant influence over one another by means of internal feedbacks. In non-equilibrial systems, which evidence suggests are those in which precipitation CVs exceed about 33 percent, it is unlikely that there will be sufficient ecosystem stability for the density of grazing animals to influence significantly long-run forage availability, since this is determined primarily by variability in the external factor of precipitation itself.

Research in Mongolia has shown that this rule-of-thumb criterion is met for something in the order of half the total area of the country. Much of the rest of Inner Asia also constitutes dryland environments that are characterised by variability and non-equilibrium dynamics. The implications for pastoral development policy are 
enormous. Conventional range management practice is predicated on the idea of controlling the stocking rate of grazing animals so as to control the rate of forage exploitation and possible deterioration. As Mongolian herders know only too well, however, long-run forage condition in non-equilbrium environments is affected more by variability in precipitation.

Indigenous pastoral resource management practices based on opportunistic grazing strategies, well-adapted to non-equilibrium ecological dynamics, have proven themselves to be productive and resilient and deserve support through appropriate forms of policy reform (PALD 1993). In the area of land tenure, rather than attempt to clarify property rights over grazing land at the level of individual herders or herding camps, these should seek to build on existing, scarce institutions at community level, thereby capitalising on centuries of experience embodied in social norms of pasture use. Any other course of action would incur extremely hgh transaction costs in terms of herding livelihoods, foregone production and environmental damage. At the same time, such a process of reform would bring structures of government effectively in line with structures of effective governance in the management of natural resources.

\section{References}

ALLEN (P.), 1993. - Food for the future: conditions and contradictions of sustainability, London \& New York, John Wiley.

AUBIN (F.), 1993. - Renouveau Gengiskhanide et nationalisme dans la Mongolie postcommuniste, Cahiers d'études sur la Mediterranée orientale et le monde turco-iranien $16: 137-206$.

BAZARGÜR (D.), SHIIREV-ADIYA (C.), and CHINBAT (B.), 1992. — Territorial organisation of Mongolian pastoral livestock husbandry in the transition to a market economy, PALD Research Reports No.1, Institute of Development Studies, University of Sussex, 14p.

BEINKE (R.H.), 1994. - Natural resource management in pastoral Africa, Development Policy Review 12 : 5-27. 
BEHNKE (R.H.), SCOONES (I.), and KERVEN (C.), eds., 1993. - Range ecology at disequilibrium: new models of natural variability and pastoral adaptation in African savannas, London, Overseas Development Institute, 248p.

BINNS (T.), 1995. — People and environment in Africa. London, John Wiley.

BLAIKIE (P.) and BROOKFIELD (H.), 1987. — Land degradation and society, London \& New York, Methuen, 296p.

BOSERUP (E.), 1965. - The conditions of agricultural growth, London, Allen \& Unwin (Reprinted by Earthscan Publications, 1993, 124p).

BRAUTIGAM (D.), 1991. - Governance and economy: a review, Policy Research Working Papers No. 815, Washington, DC, The World Bank, 48p.

BROMLEY (D.W.), 1989. - Institutional change and economic efficiency, Journal of Economic Issues 23 (3) : 735-759.

BRYANT (R.L.), 1992. — Political ecology: an emerging research agenda in Third World studies, Political Geography Quarterly 11 (1) : 12-36.

CHAMBERS (R.), ed., 1989. - Vulnerability: how the poor cope, IDS Bulletin 20 (2): 1-74.

CHAMBERS (R.), 1990. - Microenvironments unobserved, Gatekeeper Series No. 22 , London. Sustainable Agriculture Programme, International Institute for Environment and Development, 16p.

CHAMBERS (R.), 1994a. - The origins and practice of participatory rural appraisal, World Development 22 (7) : 953-969.

CHAMBERS (R.), 1994b. - Participatory rural appraisal (PRA): analysis of experience, World Development 22 (9) : 1253-1268.

CHAMBERS (R.), 1994c. - Participatory rural appraisal (PRA): challenges, potentials, and paradigm, World Development 22 (10) : 1437-1454. 
CHAMBERS (R.), PACEY (A.), and THRUPP (L.A.), eds., 1989. - Farmer first: farmer innovation and agricultural research, London, IT Publications, 218p.

COLLINS (P.) and NIXSON (F.), 1993. - Managing the implementation of 'shock therapy' in a land-locked state: Mongolia's transition from the centrally planned economy, Public Administration and Development 13 : 389-407.

COOPER (L.), 1993. - Patterns of mutual assistance in the Mongolian pastoral economy, Nomadic Peoples 33 : 153-162.

DE JANVRY (A.), SADOULET (E.), and THORBECKE (E.), eds., 1993. - State, market, and civil organisations: new theories, new practices, and their implications for rural development, World Development 21(4) : 565-689.

DE WAAL (A.), 1989. - Famine that kills: Darfur, Sudan, 1984-1985, Oxford, Clarendon Press, 258p.

DREZE (J.) and SEN (A.), 1989. - Hunger and public action, Oxford, Clarendon Press, 373p.

DURNING (A.B.), 1989. - Poverty and the environment: reversing the downward spiral, Worldwatch Papers No. 92, Washington, DC, Worldwatch Institute, 86p.

EDSTRÖM (J.), 1993. — The reform of livestock marketing in post-communist Mongolia: problems for a food secure and equitable market development, Nomadic Peoples 33 : 137-152.

EGGERTSSON (T.), 1990. - Economic behavior and institutions, Cambridge, Cambridge University Press, 385p.

FERNANDEZ-GIMENEZ (M.), 1993. - The role of ecological perception in indigenous resource management: a case study from the Mongolian foreststeppe, Nomadic Peoples 33 : 31-46.

GASPER, (D.), 1993. - Entitlements analysis: relating concepts and contexts, Development and Change 24 : 679-718. 
GIl.l. (c.). 1993. - OK, the data's lousy, but it's all we've got (being a critiçue of conventional methods), Gatekeeper Series No. 38, London, Sustainable Agriculture Programme, International Institute for Environment and Development, 17p.

GRANDIN (B.), 1988. - Wealth ranking in smallholder communities: a field manual. London, IT Publications, 49p.

IBRD, 1990. - Poverty - World Development Report 1990, Oxford, Oxford University Press for The World Bank, 260p.

IVES (J.) and MESSERLI (B.), 1989. - The Himalayan dilemma: reconciling development and conservation, London, Routledge, 295p.

KORNAI (J.), 1990. - The affinity between ownership forms and coordination mechanisms: the common experience of reform in socialist countries, Journal of Economic Perspectives 4 (3) : 131-147.

KORSUN (G.) and MURRELL (P.), 1994. - Ownership and governance on the morning after: the initial results of privatisation in Mongolia, IRIS Working Papers No. 95, College Park, Maryland, Center for Institutional Reform and the Informal Sector (IRIS), University of Maryland, 27p.

LEACH (M.) and MEARNS (R.), 1991.-Poverty and environment in developing countries: an overview study, Swindon, Economic and Social Research Council, Global Environmental Change Programme, 83p.

LEE (E.), 1993. - Initiating transition in a low-income dualistic economy: the case of Mongolia, International Labour Review 132 (5-6) : 623-638.

LIPTON (M.), 1991. - A note on poverty and sustainability, IDS Bulletin 22 (4) : 1216.

LIPTON (M.) and MAXWELL (S.), with EDSTRÖM (J.) and HATASHIMA, (H.), 1992. - The new poverty agenda: an overview, IDS Discussion Papers No. 306, Institute of Development Studies, University of Sussex, 42p. 
LITTLE (P.D.) and HOROWITZ (M.M.), eds., 1987. - Lands at risk in the third world: local-level perspectives, Boulder, Westview Press, 416p.

MCNICOLL (G.) and CAIN (M.), eds., 1990. - Rural development and population: institutions and policy, Oxford, Oxford University Press, 366p.

MEARNS (R.), 1992. - Steppes towards privatisation: changing pastoral strategies, ILEIA Newsletter 8 (3) : 6-7.

MEARNS (R.), 1993a. - Pastoral institutions, land tenure and land policy reform in post-socialist Mongolia, PALD Research Reports No. 3, Institute of Development Studies, University of Sussex, 107p.

MEARNS (R.), 1993b. - Local institutions and common-pool grazing management in post-socialist Mongolia, Paper presented at the Fourth Annual Conference of the International Association for the Study of Common Property, Manila, 15-19 June 1993, 24p.

MEARNS (R.), 1993c. - Territoriality and land tenure among Mongolian pastoralists: variation, continuity and change, Nomadic Peoples 33 : 73-103.

MEARNS (R.), 1995. - "Institutions and natural resource management: access to and control over woodfuel in East Africa" in BINNS (ed. 1995) : 103-114.

MEARNS (R.), SHOMBODON (D.), et al., 1992. - Direct and indirect uses of wealth ranking in Mongolia, RRA Notes 15 : 29-38. London, Sustainable Agriculture Programme, International Institute for Environment and Development.

MILNE (E.), LEIMONE (J.), ROZWADOWSKI (F.), and SUKACHEVIN (P.), 1991. - The Mongolian People's Republic: towards a market economy, Washington, DC, International Monetary Fund, $81 \mathrm{p}$.

MPR., 1991a. - Mongolia's economic situation, the government's reform programme and the role for external aid, Ulaanbaatar, Government of Mongolian People's Republic. 
MPR., 1991b. - Mongolia - National Report to the United Nations Conference on Environment and Development (UNCED), Ulaanbaatar, Government of Mongolian People's Republic.

MURRELL (P.), DUNN (K.T.), and KORSUN (G.), 1992. - The culture of policy making in the transition from socialism: price policy in Mongolia, IRIS Working Papers No. 32, College Park, Maryland, Center for Institutional Reform and the Informal Sector (IRIS), University of Maryland, 26p.

NORTH (D.C.), 1990. - Institutions, institutional change and economic performance, Cambridge, Cambridge University Press, 152p.

NOZICK (R.), 1974. - Anarchy, state and utopia, New York, Basic Books.

O'RIORDAN (T.), 1988. — "The politics of sustainability" in TURNER (ed. 1988) : 29-50.

OSTROM (E.), ed., 1992. — Institutions and common-pool resources, Journal of Theoretical Politics 4 (3) : 243-367.

PALD, 1993. - Options for the reform of grazing land tenure in Mongolia, PALD Policy Options Papers No.1, Institute of Development Studies, University of Sussex, 27p.

PEPPER (D.), 1984. - The roots of modern environmentalism, London, Routledge, $246 \mathrm{p}$.

RAWLS (J.), 1972. - A theory of justice, Oxford, Oxford University Press.

REARDON-ANDERSON (J.), et al., eds., 1995 (forthcoming). - Continuity and change on the Mongolian steppe: climate, ecology and land use, Cambridge, Cambridge University Press.

REDCLIFT (M,) and BENTON (T.), eds. 1994. - Social theory and the global environment, London, Routledge, $271 \mathrm{p}$.

SCOONES (I.) ed., 1994. - Living with uncertainty: new directions for pastoral development in Africa, London, IT Publications, 210p. 
SCOTT (J.), 1976. - The moral economy of the peasant, New Haven, Yale University Press.

SEN (A.), 1981. - Poverty and famines: an essay on entitlement and deprivation, Oxford, Clarendon Press, 257p.

SEN (A.), 1984. - Resources, values and development, Oxford, Blackwell, 547p.

SOLIMANO (A.), 1993. - The postsocialist transitions in comparative perspective: policy issues and recent experience, World Development 21 (11): 1823-1835.

SWIFT (J.), 1989. - Why are rural people vulnerable to famine? IDS Bulletin 20 (2) : $8-15$.

SWIFT (J.), 1995 (forthcoming). — "Introduction" to Part IV of REARDONANDERSON et al. (eds. 1995).

TEMPLER (G.), SWIFT (J.), and PAYNE (P.), 1993. — The changing signficance of risk in the Mongolian pastoral economy, Nomadic Peoples 33 : 105-122.

THOMPSON (M.), HATLEY (T.), and WARBURTON (M.), 1986. - Uncertainty on a Himalayan scale, London, Ethnographica.

THRUPP (L.A.), 1993. - "Political ecology of sustainable rural development: dynamics of social and natural resource degradation" in ALLEN (ed. 1993) : 47-73.

TIFFEN (M.), MORTIMORE (M.) and GICHUKI (F.), 1993. - More people, Less erosion: environmental recovery in Kenya, London, John Wiley, $311 \mathrm{p}$.

TOULMIN (C.), 1992. - - Herding contracts: for better or for worse? ILEIA Newsletter $8(3): 8-9$.

TURNER (R.K.), 1988. - Sustainable environmental management: principles and practice, London, Belhaven Press, 292p. 
WALKER (B.H.), 1993. - Rangeland ecology: understanding and managing change, Ambio 22 (2-3) : 80-87.

WATTS (M.), 1983. - Silent violence: food, famine and peasantry in northern Nigeria, Berkeley, University of California Press, 687p.

WESTOBY (M.), WALKER (B.H.), and NOY-MEIR (I.), 1989. - Opportunistic management for rangelands not at equilibrium. Journal of Range Management $42: 266-274$. 


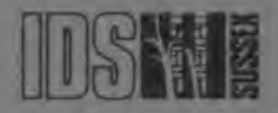

FOR FURTHER INFORMATION ON IDS PUBLICATIONS AND A FREE CATALOGUE, CONTACT:

IDS PUBLICATIONS

INSTITUTE OF DEVELOPMENT STUDIES

AT THE UNIVERSITY OF SUSSEX

BRIGHTON BN1 9RE

ENGLAND

TEL. (0273) 606261

Charitable Company No. 877338 limited by guarantee and registered in England

ISSN $1353-6141$ 